\title{
Donate to save: an analysis of the intention to donate organs under the perspective of social marketing
}

Caissa Veloso e Sousa Correio

Centro Universitário Unihorizontes

Doutora em Administração de Empresas pela Universidade Federal de Minas Gerais, na linha de pesquisa de Administração Estratégica e Mercadologia, Minas Gerais, Brasil

Jefferson Rodrigues Pereira

Centro Universitário Unihorizontes

Mestre em Administração pelo Centro Universitário Unihorizontes, Minas Gerais, Brasil

Lousanne Cavalcanti Barros Resende

Doutora em Administração pelo CEPEAD/FACE/UFMG e Pós-Doutora, em fase final, em Administração pela UNIVALI, Minas Gerais, Brasil

Leonardo Benedito Oliveira Rezende

Mestre em Administração pelo Centro Universitário Unihorizontes, Minas Gerais, Brasil

\section{Editor Científico: José Edson Lara}

Organização Comitê Científico

Double Blind Review pelo SEER/OJS

Recebido em 04.01.2017

Aprovado em 20.02.2017

\section{(c) (i) (9) \\ Este trabalho foi licenciado com uma Licença Creative Commons - Atribuição - Não Comercial 3.0 Brasil}




\begin{abstract}
In Brazil there is a growing demand for people requiring organ transplants and, secondly, a low supply of donors. In an attempt to minimize the negative impacts of this system, the government agencies responsible for attracting donors and clarification from the society can use social marketing strategies to communicate with the individuals involved in the process in order to meet social interests and improve the welfare of the population. In this context, this study aimed to identify the main variables which are related to the intention to donate organs. We conducted a survey, in which 511 fully completed surveys were collected. Factor analysis showed best fit with the extraction of four factors: reference groups; attitude; social responsibility and government campaigns. It was identified from the logit regression that gender factor and the attitude were the most important variables for the intention to donate.
\end{abstract}

Keywords: Organ Donation; Government Campaigns; Social Marketing.

\title{
Doar para salvar: uma análise da intenção de doar órgãos à luz do marketing social
}

\section{Resumo}

No Brasil há uma demanda crescente de pessoas que necessitam de transplantes de órgãos e, por outro lado, uma baixa oferta de doadores. Como tentativa de minimizar os impactos negativos desse sistema, os órgãos governamentais responsáveis pela captação de doadores e esclarecimentos à sociedade podem utilizar estratégias de marketing social para comunicação com os atores envolvidos no processo, de forma a atender aos interesses sociais e melhorar o bem estar da população. Nesse contexto, o presente trabalho teve como objetivo identificar as principais variáveis relacionadas à intenção de doar órgãos. Foi realizada uma survey a partir da qual foram coletados 511 questionários devidamente preenchidos. A análise fatorial mostrou melhor ajuste com a extração de quatro fatores: grupos de referência, atitude, responsabilidade social e campanhas governamentais. Foi possível identificar, a partir da regressão logit, que o gênero e a atitude foram as variáveis mais importantes para a intenção de doar.

Palavras-chave: Doação de Órgãos; Campanhas Governamentais; Marketing Social. 


\section{Donar para salvar: análisis de la intención de donar órganos sobre el enfoque del marketing social}

\section{Resumen}

En Brasil hay uma demanda cresciente de personas que necesitan de transplantes de órganos y, por outro lado, uma baja oferta de donadores. Com la intención de disminuir los impactos negativos de este sistema, las entidades gubernamentales responsables por la capatación de donadores y esclarescimientos a la sociedade pueden utilizar estratégias de marketing social para la comunicación con las personas envolvidas em el processo, de manera que se atiendan los intereses sociales y se mejore el bienestar de la población. Dentro de este contexto, el presente trabajo tuvo como objetivo identificar las principales variables relacionadas a la intención de donar órganos. Fue realizada una intervención, a partir de la cual fueron completados 511 cuestionários. El análisis factorial demostró mejor ajuste com la extracción de cuatro factores: grupos de referência; actitud; responsabilidad social y campañas gubernamentales. Fue posible identificar a partir de la regresión "logit" que el género y la actitud fueron las variables mas importantes para la intención de donar.

Palabras chaves: Donación de Órganos; Campañas Gubernamentales; Marketing Social.

\section{Introduction}

The human organs donation is a subject that gathers a lot of attention since the early years of christian age. In the 2nd century, it is possible to identify reports on replacing parts of the ill with parts from others who didn't need them anymore (Nothen, 2005). In this context, the author highlights the legend upon the miracle of Saint Cosmas and Damian, who would have replaced the gangrenous leg of a christian with another obtained by a Muslim killed in combat.

Although, the transplant of human organs, with an accurate scientific technique, was only possible in the beginning of the 20th century, due to the medical researcher Alexis Carrel, who created the technique of vascular anastomosis, which allows the connection of arteries and veins to nerves (Carrel, 1963).

The 50's were a mark in evolution of human organs transplants, specially due to studies made in Paris and the successful case of a kidney transplant made in Boston, between two monozygotic twins. Such events brought clarity to the process and collaborated to the development of the immunological aspects towards the 
researches on immunosupression, which helped the decline of the rejection rate in human organs transplantations (Nothen, 2005).

In the Brazilian context, Rezende, Sousa, Pereira and Rezende (2015) highlight that nowadays it is marked by a high demand of people who need organs transplantation, and on the other hand, a small supply of donors. The authors also state that this process occurs due to diseases that weaken many human organs. When one is looking for a transplantation one find lots of people on the waiting list, which usually has only one donor who helds the hopes of those who wish to have a better life expectancy with the fulfillment of this process.

In Brazil, organs donation is regulated by Brazilian Legislation on human organs donation, by Law № 9.434, of the 4th of February 1997 (Brazil, 1997). According to the Health Ministry (2014), the number of active patients on the National Technical Registration in Brazil waiting for an organ transplantation has declined approximately $40 \%$ in the last few years. In 2008 there were 64.774 people on the waiting list, and in 2013, this number has fallen to 38.759 people. This decline is associated to a better offer on the services, on the organ's collection and in the increasing number of transplantation surgeries. Although these numbers are improving, they do not supply the needs and demands of the population.

It is highlighted that the organ donation may be done with living individuals, in cases such as liver, kidneys, lungs and marrow, or in encephalic death case, which, according to the Federal Council of Medicine (CFM), represents the irreversible stop of encephalic functions characterized as apperceptive coma, with the absence of motor response and apnea (CFM, 1997).

In this context, some donations may not succeed due to the lack of information of society on encephalic deaths, as well as bureaucratic dysfunctions that the families with relatives in this case must face (Santos \& Massarolloz, 2005). The authors highlight that the moment of donation is marked by the emotional weakness of the family that find themselves with no motivation due to the death of someone dear. Another factor that must be highlighted is the difficulty faced by health professionals in developing the process of transplantation due to the lack of training in the field and the unfamiliarity with the process (Silva \& Carvalho, 2006).

As an attempt to minimize the negative impacts of this system, the Government Institutions responsible for collecting donors and informing the society may use 
communication strategies with those involved in the process, in order to reach social interest and improve population's welfare. In this context, social marketing emerges searching for public actions that may influence behaviors, in order to promote welfare (Rezende et al., 2015).

The expression social marketing was descripted by Kotler and Zaltman (1971), in order to refer to the use of techniques of commercial marketing aiming the improvement of social welfare (Andreasen, 1994; 1995; 2002; Baker, 2005).

In this context, among the many actions of social marketing, it is highlighted those that try to convince potential donors to position themselves as pro-donations. With the presented arguments, the question that guided this study emerges: what are the main variables that are related to the intention of organ donation? In order to answer the research question the study aims to identify the main variables that are related to the intention of donating organs of individuals who live in Minas Gerais, Brazil.

\section{Social Marketing: concept, usage and theoretical perspective}

The study on social marketing has emerged with the expansion of commercial marketing's borders to areas which were not explored, such as the social political and environmental ones, as examples (Kotler \& Keller, 2006; Kotler \& Lee, 2011). The conceptualization of the expression belongs to Kotler and Zaltman (1971), to refer to the use of techniques original from commercial marketing in order to support social causes, contributing as a consequence to social welfare (French \& Blair-Stevens, 2005), using processes of marketing planning (Hunt, 2010) and marketing mix (Perreault \& McCarthy, 2002).

According to Schwartz (1971), social marketing can be seen as a way of planning programs in a large scale which aims to influence voluntary behaviors in a determined segment of individuals, with a social objective instead of a financial one.

Therefore, it is important to analyze the relationship between commercial and social marketing, which allows the identification of a selling purpose in both: the first one sells products and services, the other one sells behaviors. According to Kotler and Lee (2008), the social marketing agents seek to influence a Target audience aiming to 
(1) accept a new behavior, (for example, producing fertilizer out of leftovers), (2) reject an undesirable behavior (for example, starting to smoke), (3) modify a current behavior (for example, increasing physical activity from 3 to 5 days per wekk), or (4) quit an undesirable old habit (for example, using the cellphone while driving) (Kotler \& Lee, 2008, p. 28).

Through the presented statements, it is possible to highlight that social marketing carries conventional marketing techniques in favor of social issues, aiming to not be restricted to corporate environment, given the contribution it may offer as a mean of improving the life conditions of individuals (Kotler \& Zaltman, 1971; Buxton, 1973; Andreasen, 1994; 2002; Dickson, 2001; French \& Blair-Stevens, 2005; Rezende et al., 2015).

In this context it is important to highlight the notable academical worship of social marketing as a study field in the past few years. It is possible to find studies that deal with empirical applications of social marketing in the 70's, in which the following works are highly regarded: Social marketing: The family planning experience (El-Ansary \& Kramer Jr, 1973), a study which focused on family planning in an American state; A report on a contraceptive social marketing experiment in rural Kenya (Black \& Harvey, 1976), a study which discussed the need of contraceptives in Kenya; studies on the decline of smoking habit, as the one developed by Fox e Kotler (1980) Reducing cigarette smoking: an opportunity for social marketing?; works related to the use of condoms, Condom promotion: the need for a social marketing program in America's inner cities (DeJong, 1989) and even researches that supported the use of protection networks against mosquitos who could carry diseases in Tanzania, The economics of social marketing: the case of mosquito nets in Tanzania (Kikumbih, Hanson, Mills, Mponda, \& Schellenberg, 2005).

In this sense, it is highlighted that initial studies related to social marketing had as objectives public health issues which, according to Schneider and Luce (2014), was the most approached theme in social marketing's applications.

From the 70's until the beginning of the 21st century, the studies on social marketing became more embracing, approaching fields that were not explored before. In this sense, it is possible to identify works that try to elaborate actions on how social marketing may be used and applied in gathering resources for charity, through strategies of brand management (Hankinson, 2001); studies that aim to 
understand how to influence desirable behaviors towards social field (MckenzieMohr, 2000) and researches that seek to analyze how brand's identity with the population in non corporate organizations may modify the intention of donating something (Venable, Rose, Bush, \& Gilbert, 2005).

Schneider and Luce (2014) observe that, in recent academic publications there is an agreement that social marketing uses conventional marketing techniques aiming to influence behaviors in order to improve social welfare. In this context discussions on the ethics of who might use social marketing emerge (Hastings \& Angus, 2011), and what cannot be considered social marketing (Maibach, 2003), as an example, the linking of a social cause with a profitable organization, brand or product, as a mean of obtaining financial benefits (Donovan, 2010; Menezes, 2013).

It is reported by Kotler and Zaltman (1971), that social marketing materializes itself as a model, which its objective is to be more efficient in materializing social change when it proposes new habits by spreading pre-estabished ideas.

According to Hastings and Saren (2003), the main contribution of social marketing is in fulfilling the 'gap' between several agents involved in social problems, as governments and NGO's and the public welfare, which must happen with the conception and undersating of both parts. The authors highlight that social marketing has as basic function promoting actions that may influence behaviors in order to obtain outcomes that contribute to welfare and untangible matters (as avoiding câncer and HIV). In this sense, social marketing acts as an important moderator of society's interests and governmental organizations, aiming to identify solutions to presented problems (Hastings \& Saren, 2003).

In line with this positioning, Barboza (2012) infers that the importance of social marketing is in promoting the awareness and renovation of social patterns, in order to generate lasting behavioral changes that promote welfare in terms of physical and mental health, and as consequence, would generate a better balance in society. In this sense, it is possible to establish a conceptual association between social marketing and behaviorist theory that was based on Pavlov's "stimulous-response" model (1962; 1972).

Behaviorism started in the begining of the 20th century, and it is considered a theory until nowadays, with great importance in marketing thinking (Belch \& Belch, 2004). 
Silva (2009) highlights the emerging of behaviorism may be understood as an attempt to replace conscious, the object of study of psychology, with something of greater objectivity, supposedly.

Behaviorism suggests that an unconditioned stimulus may be replaced by a conditioning stimulus, and as an outcome, a predictable behavior in individuals, which is learned by association (Pavlov, 1962; 1972). Although, the author highlights the expected objective in process may not be achieved by using a non-conditioning stimulus.

In the context of behaviorist theory, it is important to highlight Thorndike (1898, 1913), the author responsible for some studies - Animal intelligence: an experimental study of the associative processes in animals (1898) and Education psychology (1913) - on learning developed in humans and animals. Through these, the author elaborates the Effect Law, in which every behavior that unleashes a positive outcome tends to perpetuate, while every behavior that tends to unleash a negative response ought to be eliminated.

On this prism and drawing a parallel between behaviorist theory (Pavlov, 1962; 1972), Effect Law (Thorndike, 1913; 1998) and the approach that deals with social marketing (Kotler \& Zaltman, 1971; Andreasen, 1994; 2002), it is possible to infer that the objective of the last one is to conditionate a stimulus on an individual, in order that it may be learned, accepted and shared among individuals in its social group, creating as a consequence, a socially learned behavior in an autoregulation environment.

Remarkably, social marketing is focused on the transformation process of determined individual's behavior (Kotler \& Roberto, 1989; Baker, 2005). In this sense, it is reported in Mendes' (2009) positioning, in which such a change may occur in a radical or incremental way in individual's behavior.

Regarding the process of inducing behavioral change, Kotler and Armstrong (1998) state that it occurs in four stages: the first one is related to a cognitive change, which focus on information; the second occurs through changing the individual's pattern of acting; and following the process the stage of behavioral change starts due to a common objective to the group; at last the last stage brings a change in values and beliefs of individual, achieving a consequence the stage of socially learned behavior (Kotler \& Armstrong, 1998). 
Through this scenario, it is reported to Andreasen's (2002) statements, in which every discussion contributes in the sense of providing social marketing a high level of maturity, in order that it may establish and materialize itself as a research field.

Considering the importance of social marketing campaigns, that hold off authorities measures, such as fees and penalties, to change the habit of a determined social group, the thematic is discussed on the following section.

\section{Social Marketing Campaigns}

According to Kotler and Roberto (1989), the Government, responsible for taking care of individual's welfare, turns to social marketing strategies. Among them, it is highlighted governmental campaigns that aim to influence specific behaviors of population.

A great part of these campaigns approach situations of social problems and use media, specially radio and television, as a more efficient way to acess the population, given its massive use in current society (Duailibi, Pinsky, \& Laranjeira, 2007). Recently, it is also identified the internet use as an important way of communication with target audience (Rezende et al., 2015).

Among such campaigns it is possible to highlight organ donation, blood donation, non-smoking actions, no drinking and driving actions, dengue eradication, drug abuse, child vaccination and eco-friendly behaviors. Such campaigns have a common objective, whether it is minimizing, avoiding or solving social problems (Duailibi, Pinsky, \& Laranjeira, 2007).

According to Castro and Santos (2014), social marketing campaigns are developed regarding the influence on population's behaviors in favor of a common objective. Therefore, it is used speeches that may have positive or negative focuses, promoted by diverse communication means aiming to make people aware, reinforce, alter or reject a group's behavior.

In the composition of these campaigns it is possible to find appeals that have positive focus (showing the testimonial of someone who cured itself from an illness after a transplantation) or negative focus (showing a tragic car crash with victims, after drinking and driving) (Castro \& Santos, 2014).

The authors highlight that campaigns which have positive focus seek to achieve the objective of making emotional awareness, solidarity and caring of

@@ Revista Gestão \& Tecnologia, Pedro Leopoldo, v. 17, n. 1, p. 10-35, jan./abr. 201718 
individuals based on the materialized success. On the other hand, campaigns that adopt negative focus characterize themselves by actions that may generate affective or cognitive instability of individuals, in a way they impact society and modify its behavior achieving a pre-established objective (Castro \& Santos, 2014).

Regarding emotional aspects present on social marketing campaigns, it is not possible to state that there is a superiority of positive focus towards negative ones, or vice versa. Dias (2015), while analyzing car crash campaigns found a greater adhesion of target audience to approaches that emphasize tragical cases, because they are 'emotionally stronger' and easier to be recorded in memory, better influencing behaviors.

Specifically to the organ donation case, Rezende et al. (2015) state that campaigns present focuses on positive and negative emotional approaches, simultaneously tend to be more effective. They also state that testimonials of people who have been in such situations generate a greater engagement of population.

Therefore, cognitive aspects present in campaigns should be considered, that hold off images with negative or positive focus, presenting more objective and tangible information on the interest cause (Rezende et al., 2015), despite the campaigns that embrace a mix of cognitive and affective approaches.

\section{Organ Donation}

According to data collected by World Health Organization (WHO), the group of human organs embraces all organs and tissues in human body, except reproductive tissues such as ovule, sperm, testicles, ovary, embryos, blood and its constituents (WHO, 1991). In this classification of organs and tissues it is inserted the organ donation process, which may occur between living or dead individuals, through the encephalic death of a donor.

Living donors are healthy people that voluntarily want to donate the following organs; one kidney, bone marrow, a part of liver, a part of the lungs and a part of pancreas, with no health or living needs injury. In these cases donation may be to the partner or until a fourth degree relative. The living donation to people with no family relationship may occur only under juridical action, according to law № 9.434/97, regulated by Brazilian Legislation on Human Organs Donation (Brazil, 1997). 
In the case of a dead donor, removing the tissues for transplants is under the authorization of close family or partner, which are communicated after the diagnosis of encephalic death, in which is confirmed the irreversible stop of brain functions, certificated by medical exams (MG Transplantes, 2014).

According to data of Health Ministry (2014), in Brazil the number of effective donors has increased 90\% in six years, considering the period from 2008 to 2013. The data also inform that Brazil has reached a new record in 2011, with 23.397 transplantation done by the National System of Organs, configuring the country as a reference in organs donation in the world.

Nowadays, $95 \%$ of transplant surgeries are done by the public Unified Health System (SUS), a fact that turns Brazil the biggest public system of organ transplantation in the world (Brazil, 2014).

Although the number of donations has increased, it is important to highlight that the demands of patients in the waiting list is still high. In the first semester of 2014, 37.736 patients needed a compatible donor to do a transplantation that could save their lives (Brazil, 2014).

In this sense, it is important to highlight a positive point in the history of organ donations in Brazil which was the increase on the rate of donors per million inhabitants, which has increased $38 \%$, reaching 13,5donors/million individuals in the last three years. As a comparison, the pre-established objective for the period from 2012 to 2015 was reaching 13donors/million inhabitants, which was surpassed in a period of one and a half year (Brazil, 2014).

In Minas Gerais, the entire system of organs donation is controlled by the MG Transplants Complex, which is responsible for attracting donors and distributing organs to the entire state, which occurs through the National Center of Organs Donation Capitation (CNCDO) (MG Transplantes, 2014).

In order to do a transplantation, the patient must register itself in the unified list of Minas Gerais, which is under the responsibility of MG Transplants Complex, ruled by the following criteria: "urgency, blood group compatibility, anatomical compatibility, genetic compatibility, patient's age, waiting time, among other criteria" (MG Transplantes, 2014). Table 1 presents the data on organ donation in Minas Gerais, in the first ten months of 2014. 
Table 1

Organ Donation in Minas Gerais (January to October 2014)

\begin{tabular}{l|c|l|c|c|c|c|c|c|c|c}
\hline \multicolumn{1}{c|}{ Month } & $\begin{array}{l}\text { Ja } \\
\mathbf{n}\end{array}$ & $\begin{array}{l}\mathrm{Fe} \\
\mathbf{b}\end{array}$ & $\begin{array}{l}\mathbf{M a} \\
\mathbf{r}\end{array}$ & $\begin{array}{l}\mathbf{A p} \\
\mathbf{r}\end{array}$ & $\begin{array}{l}\mathbf{M a} \\
\mathbf{y}\end{array}$ & $\begin{array}{l}\mathrm{Ju} \\
\mathbf{n}\end{array}$ & $\begin{array}{l}\mathrm{Ju} \\
\mathbf{l}\end{array}$ & $\begin{array}{l}\mathbf{A u} \\
\mathbf{g}\end{array}$ & $\begin{array}{l}\mathbf{S e} \\
\mathbf{p e}\end{array}$ & $\begin{array}{l}\mathbf{O c} \\
\mathbf{t}\end{array}$ \\
\hline Potential Donors & 25 & 45 & 45 & 40 & 54 & 51 & 52 & 55 & 69 & 54 \\
\hline Effective Donors & 23 & 20 & 13 & 23 & 19 & 30 & 27 & 19 & 29 \\
\hline One Organ Donors & 23 & 0 & 2 & 0 & 1 & 6 & 3 & 2 & 8 \\
\hline Multiple Organs Donors & 22 & 15 & 20 & 13 & 20 & 17 & 30 & 23 & 17 & 21 \\
\hline Organs and Tissues Donors & 1 & 15 & 19 & 13 & 21 & 18 & 22 & 25 & 18 & 27 \\
\hline Donors (Cardiorespiratory stop) & 1 & 1 & 0 & 1 & 0 & 0 & 0 & 0 & 0 & 0 \\
\hline Family Interviews & 32 & 22 & 25 & 25 & 34 & 25 & 40 & 36 & 24 & 36 \\
\hline Family's negative answers & 16 & 10 & 12 & 13 & 11 & 10 & 14 & 8 & 16 & 14 \\
\hline
\end{tabular}

Source: Developed by the authors based on date of Health Ministry (2014).

It is observed in Table 1 that in the period between January and October 2014 there were 533 potential donors, who 221 the donation was effective, what represents $41,46 \%$. The considered percentage is relevant to Health Ministry, and it contributed to the positioning of the State among the three first places in the transplantation national ranking in Brazil (Brazil, 2014).

In this context, an important point to be highlighted is the logistic system involved in the process of organs donation, since many organs after being extracted from its donor demand many procedures to maintain its perfect conditions, as well as the short time gap to be transplanted (Brazil, 2002; Nothen, 2005).

\section{Methodology}

The present work has a quantitative approach and is classified as descriptive research, since it proposes discussing, knowing and interpreting a determined reality without any intervention (Churchill, 1987). It also aims to create opinions, attitudes and beliefs in a population (Gil, 2002).

The primary data collection was given by a survey made in electronic and printed ways. Despite the descriptive issues, the research instrument contains 52 affirmatives in a Likert scale of 7 points, from "totally disagree" in 1 to "totally agree" in 7. The variables that compose this scale were developed based on 10 constructs (attitude, information, security, socially learned behavior, motivation, reference 
groups, experimental aspects, satisfaction, social responsibility and governmental campaigns).

Data were collected in a transversal character, during the period of four months between February and May 2015. The survey was submitted to two pre-tests before its final validation, and data were computed and analyzed through SPSS software, version 19.

The research sample was selected by non-probabilistic sampling, through the "snowball" technique which, according to Malhotra (2012), enables the researcher to choose a random group of interviewees that, successively spread and refer the research to other interviewees. The sample was limited to the state of Minas Gerais.

To calculate the size of the sample, it was considered the propositions of Hair Jr, Black, Babin, Anderson and Tatham (2005) which the analysis case involve a multivaried tecnique of factorial analysis. According to them, the sample must respect a minimum of five survey collected to each Likert scale variable, and it is ideal to reach ten observations per variable: 511 surveys were properly fulfilled, what embraces a total of 9,82 observations per variable.

Initially, it was made a descriptive analysis of data, in sequence the Chi-Square test was applied to identify the association between categorical variables. Later the exploratory factorial analysis was applied through logit regression, which enables to explain many discreet variables, through prediction of values assumed by a categorical variable (Hair Jr. et al., 2005).

\section{Presentation and analysis of data}

The analyzed sample was composed by 511 surveys collected, properly fulfilled, in which 344 (67,3\%) are female and 167 (32,7\%) are male. Despite, 219 $(42,9 \%)$ have kids and $292(57,1 \%)$ don't, and the individuals have the following ages as presented in Table 2: 


\section{Table 2}

Individuals age

\begin{tabular}{lcc}
\hline \hline \multicolumn{1}{c|}{ Age } & Frequency & Percentage \\
\hline Until 17 year & 13 & 2,5 \\
From 18 to 30 years & 197 & 38,6 \\
From 31 to 50 years & 223 & 43,6 \\
From 51 to 60 years & 59 & 11,6 \\
Above 60 years & 19 & 3,7 \\
Total & 511 & 100,0 \\
\hline \hline
\end{tabular}

Source: Research data (2016).

It is observed in Table 2 that the majority of the sample has from 18 to 50 years old, and that there is a small participation of individuals until 17 years old. Related to the interviewees' gross income, two groups are remarkable: one with $27,4 \%$, almost 4 minimum wages of $R \$ 880,00$, and the other with $24,3 \%$, representing over 7 minimum wages.

\section{Table 3}

Salary ranges of individuals

\begin{tabular}{cll|c}
\hline Salary range & \multicolumn{1}{|c|}{ Gross income } & Frequency & Percentage \\
\hline 1 & Currently unemployed & 73 & 14,3 \\
2 & Until $1.356,00$ & 96 & 18,8 \\
3 & From $\mathrm{R} \$ 1.357,00$ to $\mathrm{R} \$ 3.390,00$ & 140 & 27,4 \\
4 & From $\mathrm{R} \$ 3.391,00$ to $\mathrm{R} \$ 6.780,00$ & 124 & 24,3 \\
5 & From $\mathrm{R} \$ 6.781,00$ to $\mathrm{R} \$ 10.170,00$ & 52 & 10,2 \\
6 & From $\mathrm{R} \$ 10.171,00$ to $\mathrm{R} \$ 13.560,00$ & 16 & 3,1 \\
7 & Above $\mathrm{R} \$ 13.561,00$ & 10 & 2,0 \\
& Total & 511 & 100,0 \\
\hline
\end{tabular}

Source: Research data (2016).

From the total, $409(80 \%)$ manifested the will of donating organs, while 102 $(20 \%)$ answered they do not intend to do it, for the following reasons showed in Table 4:

\section{Table 4}

Reasons for not donating organs

\section{Main reasons}

My family does not agree with organ donation

Fear of needing the organ in another life

Not knowing who might be the receiver

Don't think it's important to donate organs

Religious issues

Fear of supporting illegal human organs market

I have health problems and my organs are not appropriate for donation

Fear of removing my organs before i'm truly dead

Source: Research data (2016). 
Remarkably, $54 \%$ of individuals who do not intend to donate organs justify it as a main reason the fear of having their organs removed before they are truly dead or supporting the illegal human organs market. Moreover, this discussion on ilegal human organs market is related to the new international crime in the 21 st century. In Brazil, this tragedy occurs silently and there are few comments on this matter in the main medias (Caldeira \& Sanchez, 2014). Brito et al. (2015), states that news are sensationalists and the lack of clarity, of programs that aware the population and support organs attraction contribute to nourish doubts and consolidates myths and prejudices that result on a more insufficient number of donors.

In contrast to the main reasons why the individuals do not donate, Table 5 presents the main feelings that are involved in the process of donating organs to individuals who are donors.

\section{Table 5}

Main feelings involved in donating organs

\begin{tabular}{l|c}
\hline \multicolumn{1}{c}{ Main Reasons } & Number \\
\hline Joy & 7 \\
Fear & 2 \\
Pleasure & 2 \\
Importance & 7 \\
Joy & 7 \\
Nothing & 7 \\
Fulfillment & 20 \\
Love one another & 174 \\
Solidarity & 190 \\
\hline \hline
\end{tabular}

Source: Research data (2016).

In this sense it is observed the social character of the main feelings in the involvement with the will of donating organs, in which the feeling of fulfillment, love one another and solidarity are the main reasons why people intend to donate organs. On the other hand, family may be considered an important influence on donation. According to interviewees, 59\% informed their respective families about their desire. This positive decision towards organ donation faces a moral aspect, as an attitude that may save other people's life, helping creating a meaning for the life and death of someone dear (Maynard, Lima, Lima, \& Costa, 2016). 


\subsection{Chi-Square test: association between categorical variables}

Aiming to investigate the association between the sociodemographic and categorical variables resulting from the application of surveys, it was developed the chi-square test (Table 6).

\section{Table 6}

Chi-square test

\begin{tabular}{l|c|c|c|c|c}
\hline \hline & Value & Df & $\begin{array}{c}\text { Significance } \\
\text { Sig. } \\
\text { (2 sides) }\end{array}$ & $\begin{array}{c}\text { Exact Sig } \\
\text { (2 sides) }\end{array}$ & $\begin{array}{c}\text { Exact Sig } \\
\text { (1 side) }\end{array}$ \\
\hline $\begin{array}{lcccc}\text { Pearon's chi-square } \\
\text { Continuity correction }\end{array}$ & 8,931 & 1 & 0,003 & & \\
$\begin{array}{l}\text { Verosimilitude ratio } \\
\text { Fisher's Exact Test } \\
\text { Linear-by-linear Association }\end{array}$ & 8,240 & 1 & 0,004 & 0,002 \\
\hline \hline
\end{tabular}

Source: Research data (2016).

It was found a statistically significant association $\left(x^{2}=8,931 ; p\right.$ value $\left.=0,003\right)$ between the variable of donating and the gender variable, indicated by the observed and expected frequencies, which reveals bigger intention in female gender (Table 7).

Table 7

Intention in donating by gender

\begin{tabular}{ll|c|c|c}
\hline \hline \multirow{4}{*}{ Feminine } & \multicolumn{2}{|c|}{ WANTS TO DONATE } & \multirow{2}{*}{ Total } \\
\cline { 3 - 4 } & Count & Yes & No & \\
\hline \multirow{7}{*}{ Masculine } & Expected count & 288 & 56 & 344 \\
& $\%$ in GENDER & $83,7 \%$ & $16,3 \%$ & $100,0 \%$ \\
& $\%$ in WANTS TO & $70,4 \%$ & $54,9 \%$ & $67,3 \%$ \\
& DONATE & 121 & 46 & 167 \\
& Count & 133,7 & 33,3 & 167,0 \\
& Expected count & $72,5 \%$ & $27,5 \%$ & $100,0 \%$ \\
& \% in GENDER & $29,6 \%$ & $45,1 \%$ & $32,7 \%$ \\
\hline \hline
\end{tabular}

Source: Research data (2016).

It was also found a statistically significant association $\left(x^{2}=62,140 ; p\right.$ value $=$ 0,023 ) (Table 8 ) between the expected feeling in donating variable and the gross income variable. 


\section{Table 8}

Chi-square test

\begin{tabular}{l|c|c|c}
\hline \hline & Value & Df & $\begin{array}{c}\text { Significance Sig. (2 } \\
\text { sides) }\end{array}$ \\
\hline Pearson's chi-square & 62,140 & 42 & 0,023 \\
Verosimilitude ratio & 66,077 & 42 & 0,010 \\
Linear-by-linear association & 0,968 & 1 & 0,325 \\
№ of valid cases & 511 & & \\
\hline \hline
\end{tabular}

Source: Research data (2016).

It was also possible to observe that the presented variables as main feelings towards donating organs, love one another and solidarity represent expressive variations when linked to salary ranges sampled, indicating that the intention on donating may depend on the income perceived by individuals, as presented in Table 9.

Table 9

Experienced feeling in donating organs

\begin{tabular}{ll|c|c|c|ccc|c|c}
\hline \multirow{2}{*}{} & & \multicolumn{7}{c}{ Gross Income $^{*}$} \\
\cline { 3 - 9 } Fulfillment & Count & $\mathbf{1}$ & $\mathbf{2}$ & $\mathbf{3}$ & $\mathbf{4}$ & $\mathbf{5}$ & $\mathbf{6}$ & $\mathbf{7}$ \\
\hline \multirow{2}{*}{ Joy } & Expected count & 3,4 & 3 & 5 & 6 & 6 & 1 & 1 \\
& Count & 2 & 0 & 3 & 1 & 1 & 0 & 0 \\
\multirow{2}{*}{ Fear } & Expected count & 1,0 & 1,3 & 1,9 & 1,7 &, 7 &, 2 &, 1 \\
\hline \multirow{2}{*}{ Pleasure } & Count & 4 & 1 & 6 & 5 & 2 & 0 & 0 \\
& Expected count & 2,6 & 3,4 & 4,9 & 4,4 & 1,8 &, 6 &, 4 \\
\hline \multirow{2}{*}{ Love one another } & Count & 0 & 1 & 1 & 0 & 0 & 0 & 0 \\
& Expected count &, 3 &, 4 &, 5 &, 5 &, 2 &, 1 &, 0 \\
\hline \multirow{2}{*}{ Importance } & Count & 32 & 54 & 67 & 40 & 12 & 2 & 6 \\
& Expected count & 30,4 & 40,0 & 58,4 & 51,7 & 21,7 & 6,7 & 4,2 \\
\hline \multirow{2}{*}{ Solidarity } & Count & 0 & 4 & 1 & 1 & 1 & 0 & 0 \\
& Expected count & 1,0 & 1,3 & 1,9 & 1,7 &, 7 &, 2 &, 1 \\
\hline \multirow{2}{*}{ Nothing } & Count & 31 & 30 & 55 & 63 & 30 & 12 & 3 \\
& Expected count & 32,0 & 42,1 & 61,4 & 54,4 & 22,8 & 7,0 & 4,4 \\
\hline \hline
\end{tabular}

Source: Research data (2016)

*Note: the inferior and superior values of each salary range are presented in Table3

Remarkably, then the chi-square test is done between intention for donating and memories of messages of publicity campaigns variables, it was not possible to obtain a statistically significant outcome, reflecting what seems to be a lack of efficiency in publicity that support organ donation. 


\subsection{Factorial Analysis and logit regression}

The survey applied is composed by 52 Likert scale questions, which were analyzed by an exploratory factorial approach. To generate the factorial analysis model it was considered the communalities above 0,5 , obtained by rotational methods of Varimax extraction. It was also tested the internal consistency considering all the factors that presented Cronbach's Alfa above 0,8. The outcome obtained was 0,800 suggesting an average adequacy of adjust to the model, to do the factorial analysis, according to Table 10. The Sig., that refers to the significance test suggests the technical adequacy with the inferior outcome to the one desirable at 0,05 .

\section{Table 10}

KMO and Bartlett test

\begin{tabular}{lc}
\hline Kaiser-Meyer-Olkin Measure of Sampling Adequacy &, 800 \\
Bartlett's Test of Sphericity & 3399,740 \\
Df & 120 \\
Sig &, 000 \\
\hline Source: research data (2016).
\end{tabular}

In a second moment, the model generated 14 factors with an explanation on degree around $62,799 \%$. Seeking better results it was analyzed the anti-image matrix and the communalities. With the requirements for each analysis, and removing the variables with values below 0,500 , it was identified an improvement on explanation to $63,748 \%$, with 4 factors. 


\section{Table 11}

Rotated Matrix Components

\begin{tabular}{|c|c|c|c|c|}
\hline \multirow{2}{*}{ Variables } & \multicolumn{4}{|c|}{ Components } \\
\hline & 1 & 2 & 3 & 4 \\
\hline Talks with friends about organs donation & & & & ,831 \\
\hline My work/school supports organs donation & & & 883 & \\
\hline Talks with family about organs donation & & & & ,786 \\
\hline Government's campaigns influenced me to be a donor & & ,717 & & \\
\hline Government's campaigns on organs donation are efficient & & 739 & & \\
\hline $\begin{array}{l}\text { To know that one's organ saved another's life soothes one's } \\
\text { family mourning }\end{array}$ & ,853 & & & \\
\hline To be a donor makes me happy & ,792 & & & \\
\hline To be a donor makes me proud & &, 753 & & \\
\hline Society is well informed on organs donation & & ,808 & & \\
\hline $\begin{array}{l}\text { I would donate an organ while alive if someone dear needed } \\
\text { it }\end{array}$ & ,799 & & & \\
\hline Would like that my family donated my organs & ,765 & & & \\
\hline $\begin{array}{l}\text { In my professional/academic environment there are organs } \\
\text { donation campaigns }\end{array}$ & & & ,879 & \\
\hline $\begin{array}{l}\text { I'm aware about organs donation due to my } \\
\text { professional/academic environment }\end{array}$ & & & ,804 & \\
\hline Thinks organs donation is important for society & ,535 & & & \\
\hline Tries to convince other people to be donors & & & &, 784 \\
\hline To donate is a citizen's duty & ,415 & & & \\
\hline
\end{tabular}

The final outcome of the factorial analysis generated 4 factors. The importance of understanding the intention may influence in the attitude of donating organs and understanding the individual's acting before a determined behavior is a part of the first factor. To the second one, the variables have characteristics related to government's acting. According to Portal Brasil (2015) data, besides the videos that are shared in social medias, the campaign is published in posters, broadside (publicitar frames), marketing e-mails directed to health professionals, despite the actions in movies, which intends to raise the importance of letting familiars aware of the will of donating organs. 2015's slogan was "Living is a great conquer. Help other people to become winners". In 2016, the new edition of the campaign promoted by the Health Ministry makes references to sports and the Olympic and Paralympic Games.

The third factor has characteristics of reference groups, that may be seen as one of the main conditioning factors in the motivational process of behavior, since these groups, through relationships socially build contribute to the creation of values and beliefs of individuals (Schiffman \& Kanuk, 2003).

And, at last, the fourth factor is related to socially learned behavior. The changes happen in the attitudes' pattern of individuals, following the stage of 
behavioral change in individuals in favor of a common objective shared by the group, and lastly the stage brings the change in values and beliefs of individuals, achieving the stage of socially learned behavior (Kotler \& Armstrong, 1998)

After the results of factorial analysis, the variables were used alongside with sociodemographic variables in a model of logit regression in which was used the prediction of the categorical variable donating intention. It followed the association between independent variables analysis and the donating intention variable, as it is observed in Table12.

To evaluate the importance of each variable in the model was verified the statistics of Wald's test applied individually (Table12), where it is possible to observe that the "Gender" (Wald=3,351; $p=0,067$ ) and "Attitude" (Wald=78,238; $p=0,000$ ) variables are significantly associated to donating intention, indicating that there is enough evidence that the $\beta$ coefficients are different from zero.

\section{Table 12}

Equation Variables

\begin{tabular}{l|c|c|c|c|c|c}
\hline \hline & B & S.E. & Wald & Df & Sig. & Exp(B) \\
\hline Reference Groups & 0,014 & 0,019 & 0,568 & 1 & 0,451 & 1,015 \\
Attitude & $-0,236$ & 0,027 & 78,238 & 1 & 0,000 & 0,790 \\
Social Responsability & $-0,015$ & 0,033 & 0,200 & 1 & 0,655 & 0,985 \\
Government's campaigns & 0,026 & 0,030 & 0,771 & 1 & 0,380 & 1,027 \\
GENDER (1) & $-0,584$ & 0,319 & 3,351 & 1 & 0,067 & 0,558 \\
CHILDREN (1) & $-0,080$ & 0,357 & 0,050 & 1 & 0,823 & 0,923 \\
FAIXET & & & 1,044 & 4 & 0,903 & \\
FAIXET (1) & $-0,874$ & 1,205 & 0,526 & 1 & 0,468 & 0,417 \\
FAIXET (2) & $-0,613$ & 0,734 & 0,697 & 1 & 0,404 & 0,542 \\
FAIXET (3) & $-0,488$ & 0,692 & 0,499 & 1 & 0,480 & 0,614 \\
FAIXET (4) & $-0,258$ & 0,756 & 0,116 & 1 & 0,733 & 0,772 \\
Constant & 5,310 & 1,191 & 19,868 & 1 & 0,000 & 202,273 \\
\hline \hline
\end{tabular}

Source: Research data (2016).

The outcomes of logit regression confirmed the importance of the gender and attitude variables (operationalized through sum of referring scores to component questions of attitude factor resulting from factorial analysis) in the donation intention of sampled individuals.

\section{Final Considerations}

The present work had as objective the investigation of variables related to individual's intention in donating organs. Alongside with technological evolution, 
organs donation has contributed to save lives, what gives to it a great role in government's schedule.

The results of the research indicate that the majority of individuals who answered intend to donate organs, highlighting a greater intention in female individuals. Timely, the main feelings signed in the involvement with donating intention of respondents are essentially social, highlighting "love one another" and "solidarity", the last one being expressive even in groups with larger incomes.

Remarkably, approximately half of the individuals who informed they do not intend to donate justified it by the fear of having their organs removed before they're dead or to support illegal organ's market, revealing that the effects of lack of security are currently found in many areas of quotidian life, what may unfortunately keep people from donating.

Among the many sociodemographic variables investigated, only gender showed some consistent relevance in every developed analysis. It was not found, although any explanation for this phenomenon, what raises questions for future studies:

Among the many factors extracted through factorial analysis, the attitude showed itself as statistically significant in predicting the intention of donating, differently from factors of social responsibility, reference groups and government's campaigns. Different from the alleged importance in studies on the role of reference groups in individual's behavior, the results found suggest that the intention of donating depends essentially on the evaluative answer, on the individual's attitude towards social needs, which seems to be generated from other factors than government's campaigns for supporting donation.

As constraints in the present study it is highlighted its limitation to individuals who live in the state of Minas Gerais.

For future research, it is recommended the development of broad qualitative studies, especially those that use this approach relating organs donation with the constructs found through exploratory factorial analysis in this study (reference groups, attitude, social responsibility and government's campaigns), in order to understand in a greater level of depth the results found in this study. It is also suggested the investigation on the motivating factors in female individuals, considering the outcomes found in this study, following gender distribution. 


\section{References}

Andreasen, A. R. (1994). Social marketing: Its definition and domain. Journal of public policy \& marketing, 13(1), 108-114.

Andreasen, A. R. (1995). Marketing social change: changing behavior to promote health, social development, and the environment. Michigan: Jossey-Bass.

Andreasen, A. R. (2002). Marketing social marketing in the social change marketplace. Journal of Public Policy \& Marketing, 21(1), 3-13.

Baker, M. J. (2005). Administração de Marketing. Rio de Janeiro: Elsevier.

Barboza, S. I. S. (2012). Marketing social aplicado à doação de sangue: fatores condicionantes de comportamento. (Dissertação de Mestrado. Universidade Federal da Paraíba, João Pessoa, PB, Brasil).

Belch, G.E., \& Belch, M.A. (2004). Advertising and Promotion: An Integrated Marketing Communication Perspective. New York: McGraw-Hill.

Black, T. R., \& Harvey, P. D. (1976). A report on a contraceptive social marketing experiment in rural Kenya. Studies in Family Planning, 101-108.

Brasil. (1997). Lei n. 9.434, de 4 de fevereiro de 1997. Diário Oficial [da] União. Recuperado de <www.idp.edu.br/.../450-legislacao-brasileira-sobre-doacao-deorgaos $>$.

Brasil. (2002). Legislação Brasileira Sobre Doação de órgãos humanos. Recuperado de <www.idp.edu.br/.../450-legislacao-brasileira-sobre-doacao-de-orgaos $>$.

Brasil. (2014). Ministério da Saúde. Sistema nacional de transplantes. Recuperado de <http://www.brasil.gov.br/saude/2012/02/transplantes-dobram-no-pais-em-10anos $\geq$.

Brito, F. P. G., Carvalho, T. B., Silva, H. C., Nogueira, E. C., Fernandez, B. O., Aguiar, R. R. S., \& Santana, K. I. S. P. (2015). Um olhar sobre ações educativas voltadas para doações de órgãos e tecidos: uma revisão de literatura. Interfaces Científicas-Saúde e Ambiente, 4(1), 55-62.

Buxton, G. (1973). The role of the comparative analysis approach in social marketing. European Journal of Marketing, 7(1), 55-63.

Caldeira, G. G., \& Sanchez, C. J. P. (2014). Transplantes de órgãos e tecidos. ETIC 2014 - Encontro de iniciação científica, Toledo Prudente Centro Universitário.

Carrel, A. (1963). The Operative Technique of Vascular Anastomoses and the Transplantation of Viscera. Clinical Orthopaedics and Related Research, 29, 3-6. 
Castro, I. M. \& Santos, P. M. F. (2014). O Efeito de Campanhas de Marketing Social com Apelos Negativos no Comportamento de Risco das Pessoas que Ingerem Bebidas Alcoólicas. Anais do 38ํㅡㄹ Encontro de Administração Pública e Governança, Belo Horizonte, MG, Brasil.

Churchill Jr., G. A. (1987). Marketing research: methodological foundations. Chicago: The Dryden Press.

Conselho Federal de Medicida - CFM. (1997). Resolução, CFM no 1480 de 08 de agosto de 1997. Estabele critérios diagnósticos de morte encefálica: Conselho Federal de Medicina.

DeJong, W. (1989). Condom promotion: the need for a social marketing program in America's inner cities. American Journal of Health Promotion, 3(4), 5-16.

Dias, R. G. (2015). O uso de metáforas na análise da eficácia das campanhas de marketing social sobre a prevenção aos acidentes de trânsito: um estudo com condutores habilitados. (Dissertação de Mestrado em Administração. Faculdade Novos Horizontes, Belo Horizonte, MG, Brasil).

Dickson, P. R. (2001). Ambiente de Marketing e Responsabilidade Social. Porto Alegre: Bookman.

Donovan, R. \& Henley, N. (2010). Principles and practice of social marketing: an international perspective. New York: Cambridge University Press.

Duailibi, S., Pinsky, I., \& Laranjeira, R. (2007). Prevalência do beber e dirigir em Diadema, estado de São Paulo. Rev Saúde Pública 41(6), 1058-61.

El-Ansary, A. I., \& Kramer Jr, O. E. (1973). Social marketing: The family planning experience. The Journal of Marketing, 1-7.

Fox, K. F., \& Kotler, P. (1980). Reducing cigarette smoking: an opportunity for social marketing? Journal of health care marketing, 1(1).

French, J., Blair-Stevens, C. (2005). Social marketing pocket guide. London: National.

Gil, A.C. (2002). Como elaborar projetos de pesquisa. São Paulo: Atlas.

Hair Jr, J. F., Black, W. C., Babin, B. J., Anderson, R. E., \& Tatham, R. L. (2005). Análise multivariada de dados. Bookman Editora.

Hankinson, P. (2001). Brand orientation in the Top 500 fundraising charities in the UK. Journal of Product \& Brand Management, 10(6), 346-360.

Hastings, G., \& Angus, K. (2011). When is social marketing not social marketing? Journal of Social Marketing, 1(1), 45-53. 
Hastings, G., \& Saren, M. (2003). The critical contribution of social marketing theory and application. Marketing theory, 3(3), 305-322.

Hunt, S.D. (2010). Marketing Theory: Foundations, controversy, strategy, resourceadvantage theory. New York: M. E. Sharpe.

Kikumbih, N., Hanson, K., Mills, A., Mponda, H., \& Schellenberg, J. A. (2005). The economics of social marketing: the case of mosquito nets in Tanzania. Social Science \& Medicine, 60(2), 369-381.

Kotler, P., \& Armstrong, G. (1998). Princípios de Marketing (7a ed.). Rio de Janeiro: Prentice-Hall.

Kotler, P., \& Keller, K.L. (2006). Administração de marketing. São Paulo: Pearson Prentice Hall.

Kotler, P., \& Lee, N. R. (2008). Marketing no setor público. Porto Alegre: Bookman.

Kotler, P., \& Lee, N. R. (2011). Social marketing: influencing behavior for good (4a ed.). SAGE Publications.

Kotler, P., \& Roberto, E. L. (1989). Social marketing. Strategies for changing public behavior. New York: Free Press.

Kotler, P., \& Zaltman, G. (1971). Social marketing: an approach to planned social change. The Journal of Marketing, 3-12.

Maibach, E. W. (2003). Explicating social marketing: what is it, and what isn't it? Social Marketing Quarterly, 8(4), 7-13.

Malhotra, N. K. (2012). Pesquisa de Marketing: uma orientação aplicada (6a ed.). Porto Alegre: Bookman.

Mckenzie-Mohr, D. (2000). New ways to promote proenvironmental behavior: Promoting sustainable behavior: An introduction to community-based social marketing. Journal of social issues, 56(3), 543-554.

Mendes, L. (2009). A Gênese do Marketing Social nas Ideias de Biopolítica e Biopoder de Michel Foucault: Considerações Críticas. Anais do $33^{\circ}$ Encontro Nacional da Associação Nacional de Pós-Graduação em Administração, São Paulo, SP, Brasil.

Mg Transplantes. (2014). FHEMIG. Recuperado de $<$ http://www.fhemig.mg.gov.br/atendimento-hospitalar/complexo-mgtransplantes>.

Maynard, L. O. D., Lima, I. M. S. O., Lima, Y. O. R., \& Costa, E. A. (2016). Os conflitos do consentimento acerca da doação de órgãos post mortem no brasil. Revista de Direito Sanitário, 16(3), 122-144. 
Menezes, A. G. (2013). Comportamento do doador de sangue: aspectos experienciais e motivacionais. 2013. Dissertação (Mestrado em Administração). Faculdade Novos Horizontes, Belo Horizonte.

Ministério da Saúde. (2014). Sistema nacional de transplantes. Recuperado em 16 out., 2014 de http://portalsaude.saude.gov.br/index.php/cidadao/principal/campanhaspublicitarias/16547-doacao-de-orgaos-2015

Nothen, R. R. (2005). A doação de órgãos no cenário brasileiro. Associação Brasileira de Transplante de órgãos. São Paulo.

Pavlov, I. (1962). Obras escolhidas. São Paulo: Fulgor.

Pavlov, I. (1972). Reflexos condicionados e inibições. Rio de Janeiro: Zahar.

Perreault, W. D; McCarthy, E. J. (2002). Basic Marketing: A global-managerial approach. New York: McGraw-Hill.

Portal Brasil. (2015). Campanha sobre doação de órgãos destaca histórias de atletas transplantados. Recuperado de http://www.brasil.gov.br/saude/2015/10/campanha-de-doacao-de-orgaos-trazhistorias-de-atletas-transplantados

Rezende, L. B. O., Sousa, C. V. E., Pereira, J. R., \& Rezende, L. D. O. (2015). Doação de Órgãos no Brasil: Uma Análise das Campanhas Governamentais sob a Perspectiva do Marketing Social. REMark - Revista Brasileira de Marketing, 14(3), 362-76.

Santos, M. J., \& Massarolloz, M. C. K. B. (2005). Processo de doação de órgãos: percepção de familiares de doadores cadáveres. Rev Latino-am Enfermagem, 13(3), 382-7.

Schwartz, G. (1971). Marketing: the societal concept. University of Washington Business Review, 31(1), 33-38.

Schneider, G., \& Luce, F. B. (2014). Marketing Social: Abordagem Histórica e Desafios Contemporâneos. REMark - Revista Brasileira de Marketing, 13(3), 125.

Sheth, J. N., Gardner, D. M., \& Garrett, D. E. (1988). Marketing theory: evolution and evaluation (Vol. 1). New York, NY: Wiley.

Silva, T. C., \& Carvalho, R. (2006). Transplante Hepático: Problemas de Enfermagem em Pacientes no Pós-Operatório. Jornal Brasileiro de transplantes, $9(1), 481-485$. 
Silva, M.A. (2009). O comportamento do consumidor adolescente brasileiro: a propaganda como possível agente de influência determinante de sua decisão de compra. 2009. (Dissertação Mestrado em Psicologia Cognitiva, Universidade Federal de Pernambuco - UFPE, Recife, Brasil).

Thorndike, E. L. (1898). Animal intelligence: An experimental study of the associative processes in animals. The Psychological Review: Monograph Supplements, 2(4).

Thorndike, E. L. (1913). Educational psychology. Teachers college, Columbia university.

Venable, B. T., Rose, G. M., Bush, V. D., \& Gilbert, F. W. (2005). The role of brand personality in charitable giving: An assessment and validation. Journal of the Academy of Marketing Science, 33(3), 295-312.

World Health Organization (WHO). (1991). Human organ transplantation. Geneva. 